Article

\title{
Deglaciation Rate of Selected Nunataks in Spitsbergen, Svalbard-Potential for Permafrost Expansion above the Glacial Environment
}

\author{
Joanna Ewa Szafraniec *(D) and Wojciech Dobiński $(\mathbb{D}$ \\ Institute of Earth Sciences, Faculty of Natural Sciences, University of Silesia in Katowice, Będzińska 60, \\ 41-200 Sosnowiec, Poland; wojciech.dobinski@us.edu.pl \\ * Correspondence: joanna.szafraniec@us.edu.pl; Tel.: +48-3236-89-687
}

Received: 8 April 2020; Accepted: 22 May 2020; Published: 25 May 2020

\begin{abstract}
Spitsbergen has recently experienced a continuous deglaciation process, linked to both glacier front retreat and lowering of the glacier surface. This process is accompanied by permafrost aggradation from the top of the slopes down to the glacier. Here, the authors determine the rate of permafrost expansion in this type of vertical profile. To this end, seven nunataks across the island were analysed using Landsat satellite imagery, a high-resolution digital elevation model (ArcticDEM), and geoinformation software. Over the last 24-31 years, new nunataks gradually emerged from the ice cover at an average linear rate of $0.06 \mathrm{~m} \mathrm{a}^{-1}$ per degree of increment of the slope of the terrain at an average altitude of approximately $640 \mathrm{~m}$ a.s.l. The analysis showed that the maximum rate of permafrost expansion down the slope was positively correlated with the average nunatak elevation, reaching a value of approximately $10,000 \mathrm{~m}^{2} \mathrm{a}^{-1}$. In cold climates, with a mean annual air temperature (MAAT) below $0{ }^{\circ} \mathrm{C}$, newly exposed land is occupied by active periglacial environments, causing permafrost aggradation. Therefore, both glacial and periglacial environments are changing over time concomitantly, with permafrost aggradation occurring along and around the glacier, wherever the MAAT is negative.
\end{abstract}

Keywords: Spitsbergen; permafrost aggradation; deglaciation; nunataks; glaciers; climate warming

\section{Introduction}

Glacial and periglacial environments are frequently perceived and investigated as fully differentiated entities [1,2]. This is mainly because permafrost is defined as a thermal state of the lithosphere: ice or rock [3-7], while glaciers are defined as the material consequence of the accumulation, metamorphism and movement of the different types of ice forming a glacier [8,9]. Negative temperatures are the common feature to both concepts, representing a sine qua non condition for creating both glaciers and permafrost.

The processes associated with permafrost are only aggradation or degradation [4]. In general its aggradation occurs everywhere where the heat balance on the Earth's surface is negative, and usually is related to the mean annual air temperature (MAAT) ca. $-1{ }^{\circ} \mathrm{C}$ or lower [1-3].

Svalbard is an area where the MAAT is $-1{ }^{\circ} \mathrm{C}$ or lower everywhere, which means that each part of the area exposed to direct climate influence fulfill those conditions and develops permafrost as soon as the glaciers recede.

The Arctic is largely covered by both land under long-term negative ground temperature and ice. Glacial and periglacial environments are also found outside the polar regions in the alpine zone, with large parts of Europe, Asia and North America [2,10,11] being covered by these environments intermittently over the Pleistocene. From the very general point of view, glaciers require a rather large 
accumulation of snow instead of a very low air temperature, whilst negative temperatures are the main driver of permafrost aggradation.

The glacier-permafrost relationship is quite difficult to characterize, mainly due to their differing defining nature, while permafrost is a physical condition (temperature), glaciers are material feature (ice/moraine). Recent studies have focused on approximating the definition of both glacial and periglacial systems through identifying permafrost as a type of underground ice; however, opinions on the glacier-permafrost relationship front are still divided [12-18].

Nunataks, sharp peaks protruding over glacier ice, are a characteristic element of Svalbard's geomorphology. Their altitudes vary, reaching even above $1700 \mathrm{~m}$ a.s.l. in the NE of Spitsbergen (Newtontoppen), or above $1400 \mathrm{~m}$ a.s.l. in the southern part (Hornsundtind). During the Last Glacial Maximum, many were completely covered by ice. Recent global warming, however, is causing the further emergence of nunataks from under the ice, supplying mineral material to the middle and lateral moraines of the separating tributaries of the valley glaciers. In this study, attention was paid to the rate of emergence of new slopes depending on their exposure and elevation range.

The purpose of this work is to present the potential development of the periglacial zone covered by permafrost not below, but above glaciated areas, at the highest altitudes due to vertical recession of higher located parts of the glaciers in Spitsbergen. Glacial recession involves both glacier front retreat and the lowering of the glacier surface also in its accumulation area, as a consequence of the changes of entire geometry, thermics and dynamics of the glacier and surrounding periglacial areas. Thus, the area dominated by nunataks and mountain slopes is also expected to significantly increase through deglaciation.

\section{Research Area}

The spatial analysis presented here is based on satellite images from Spitsbergen, the largest island of the Svalbard archipelago. Approximately $60 \%$ of its area is permanently covered by different type of glacial ice. Large ice-caps dominate, bringing out complex systems of outlet valley glaciers separated by mountain ridges and nunataks. There are also many small cirques glaciers, especially in the western parts of Spitsbergen. Most glaciers are subpolar-polythermal, with their margins and parts of the ablation area below the pressure-melting point $(\mathrm{PMP})\left(<0{ }^{\circ} \mathrm{C}\right)$, and therefore frozen to the ground. The accumulation part is considered temperate (at the PMP). Many small mountain glaciers are cold-type forms [19].

Ice-free areas generally are configured as continuous permafrost. According to Humlum et al. [20], continuous permafrost in Svalbard reaches a thickness of approximately $100 \mathrm{~m}$ in the larger, non-glacial valleys, and down to 400-500 $\mathrm{m}$ in high altitudes. The recession of Pleistocene glaciation around Longyearbyen, in the centre of Spitsbergen, commenced 14,250 \pm 300 years BP [21]. Therefore, deep lying permafrost can be assumed to be a relict from before the Last Glacial Maximum [22].

Glacial ice isolates the ground from very low air temperatures. In addition, the friction caused by the glacier movement transfers some energy to the ground underneath, that linked to any geothermal heat, could reduce the thickness of the permafrost. These processes combined cause a degradation of the permafrost of approximately $0.01 \mathrm{~m} \mathrm{a}^{-1}$ [23], but it has not led to its complete disappearance anywhere, to the best of the authors' knowledge. These processes can be also assumed to have caused a permafrost degradation of approx. $300 \mathrm{~m}$ of its thickness during the Würm period. As a consequence, mountain permafrost may have not disappeared completely and its age can be estimated to be around 700,000 years [20]. The contemporary permafrost has mainly developed during the Holocene. In Spitsbergen, permafrost covers all the unglaciated area, i.e. 40\%, or approximately $15,600 \mathrm{~km}^{2}$. However, Western Spitsbergen has been experiencing a substantial warming over the most recent years, reaching an average increase in temperature of 3.4-4.6 ${ }^{\circ} \mathrm{C}$ (1971-2015), particularly in winter [24]. Consequently, the coast of Spitsbergen might be already covered only by discontinuous permafrost or permafrost in a cryotic state [25-27]. 


\section{Climate}

Climate is very important for the development of the periglacial zone and especially for the development and maintenance of permafrost. The mean annual air temperature (MAAT) on the coast of Spitsbergen reaches $-6{ }^{\circ} \mathrm{C}$, remaining between $-4{ }^{\circ} \mathrm{C}$ in the south and $-7^{\circ} \mathrm{C}$ in the north of the archipelago [28]. The temperature in mountains is much lower. For example, the MAAT measured in Janssonhaugen for the period $1978-1998$ was $-7.8^{\circ} \mathrm{C}$ [29]. Mean altitudinal gradient fluctuates between 0.71 and $0.74{ }^{\circ} \mathrm{C}$ per $100 \mathrm{~m}$ of elevation [30]. This means that the MAAT may fall well below $-15{ }^{\circ} \mathrm{C}$ in the highest regions (e.g., Newtontoppen, $1713 \mathrm{~m}$ a.s.l.) [31].

The scale of climate warming that occurs on Spitsbergen in relation to the described problem is documented by long-term measurements of air temperature at the Svalbard Airport. Here MAAT remains below $-1{ }^{\circ} \mathrm{C}$ with one exception in 2017 (Figure 1). This means that favorable climatic conditions for permafrost still persist, but they may change within short period of time due to visible increasing trend of $2.6^{\circ} \mathrm{C}$ per 100 years [28] and definitely higher values of MAAT in recent years. Projections, e.g., for the Hornsund area (S Spitsbergen), suggest further warming, especially the increase of winter temperatures [32]. Scenarios also predict higher sums of precipitation.

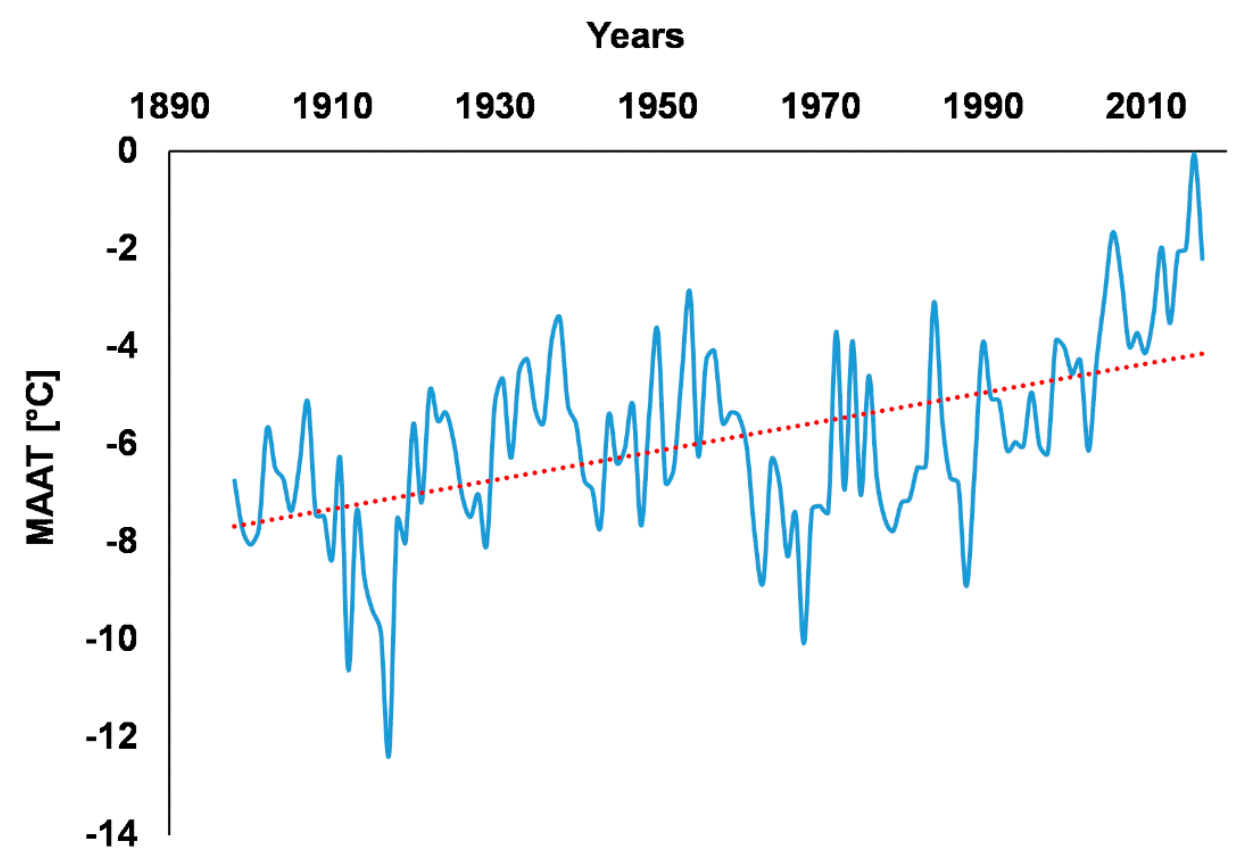

Figure 1. Mean annual air temperature (MAAT) at Svalbard Airport in the years 1898-2018, together with trend line [33].

\section{Materials and Methods}

Landsat 5 Thematic Mapper (TM) satellite scenes (1985-1992) and Landsat 8 Operational Land Imager/ Thermal InfraRed Sensor (OLI/TIRS) (2014-2017) were downloaded using Earth Explorer [34]. These images were subsequently used to identify the nunataks and distinguish their margins from the surrounding glacial ice (Figure 2; Table 1). The imagery used is publicly accessible and published by the National Aeronautics and Space Administration (NASA) and the U.S. Geological Survey (USGS). 
Colour compositions with a resolution of $30 \mathrm{~m}$ were prepared in ArcMap 10.7 (ArcGIS) using near infrared (NIR) and shortwave infrared (SWIR) channels and the red (Red) channel in the visible band (Figure 3a): 543 and 654 respectively (Data Management Tools $=>$ Raster $=>$ Raster Processing $=>$ Composite Bands). The coloured compositions were then classified by principal components (Figure 3b; Spatial Analyst Tools => Multivariate). Using the QGIS 3.8 Zanzibar software, the rasters were converted into vector layers. The red channel of the principal components allowed the automatic separation of the nunataks from the glacial ice (Figure 3c) using Digital Number $(\mathrm{DN})<130$. The glaciernunatak boundary (Figure 3d) was finally identified by manually correcting the shaded parts and moraine material on the glacier.

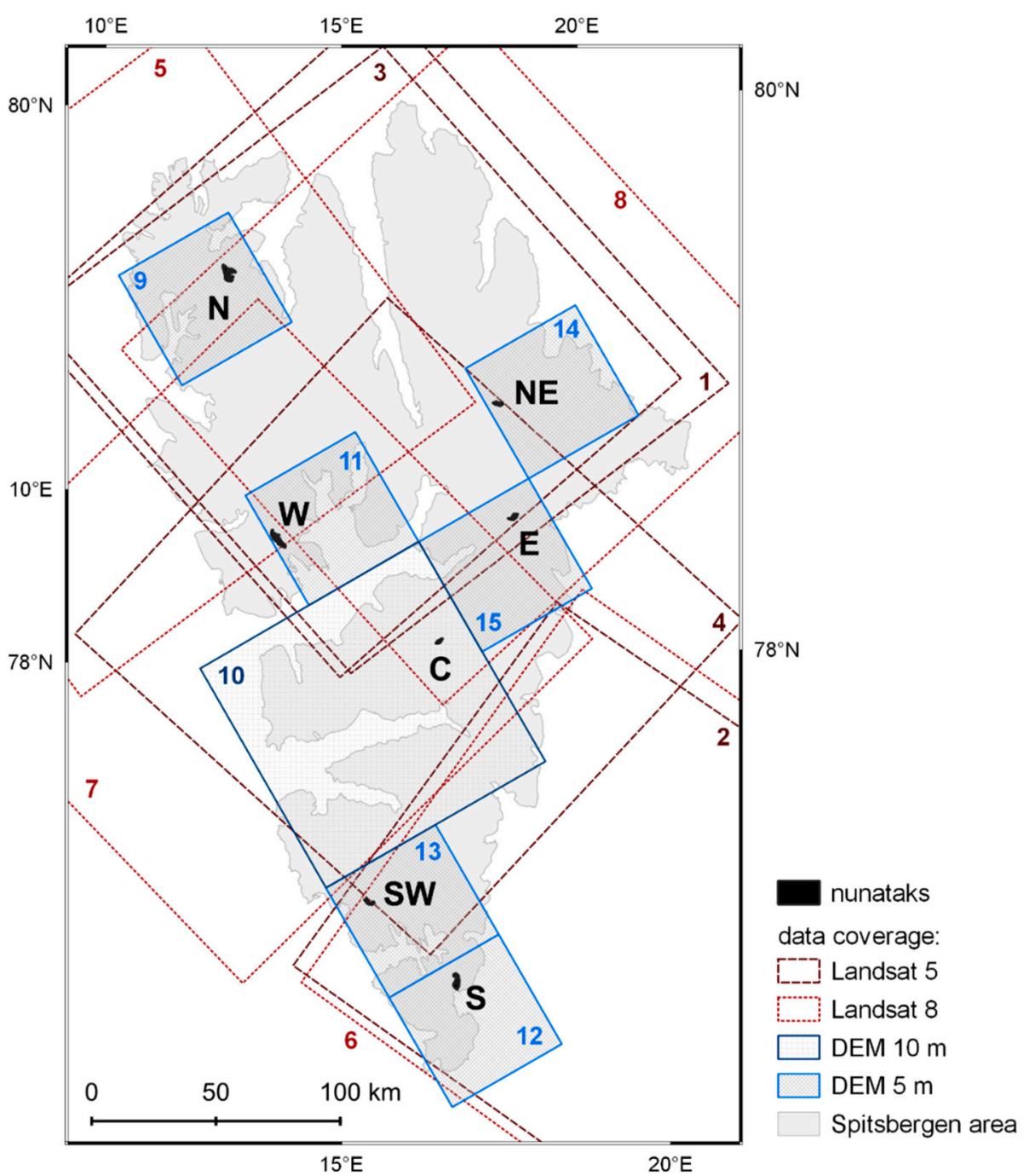

Figure 2. Area covered by the present study: region E-Malte Brunfjellet; region NE—southern part of Černyševfjellet; region S-Pulkovofjella; region N-Schivefjellet; region W-Kaosfjellet; region SW-Kverven; region C-Drøntoppen. The number labelling is explained in Table 1. 
The ArcticDEM high-resolution digital elevation model [35] was used to calculate the rate of deglaciation throughout the vertical profile. The deglaciation rate for nunataks was calculated on the basis of changes in the average nunatak elevation in the analyzed research period, then converted into meters of changes per one year. The average elevation of the nunatak is understood here as the value calculated for the parts protruding above the glaciers. The vertical deglaciation rate value per degree was calculated using the real distance of the lowering of the average nunataks altitude and the average value of the slope of nunatak walls on this line. The data had a resolution of $5 \mathrm{~m}$ for most areas (cf. Figure 2; Table 1); however, the nunatak in the central part of the island was defined with a resolution of $10 \mathrm{~m}$ due to numerous gaps in the 5-m model. ArcticDEM files (the Geodetic Parameter Set code developed by the European Petroleum Survey Group => EPSG: 3413 ) were transformed into a UTM coordinate system for the 33N zone on the WGS84 ellipsoid (EPSG: 32633). The authors of ArcticDEM have not tested the vertical accuracy of the model [36]; however, it has been defined to be below $0.5 \mathrm{~m}$ [37]. This value was subsequently verified by Glennie [38] using airborne light detection and ranging (LIDAR) over Alaska. The vertical accuracy was found to be $2-4 \mathrm{~m}$ for lower and uncovered areas but worsening in forested areas (not applicable to Spitsbergen). On the other hand, Murfitt and Duguay [39] reported a $4 \mathrm{~m}$ of vertical and horizontal accuracy for the model. In QGIS, sections of the model were cut out from the ArcticDEM files using the nunataks shape. Data for Spitsbergen glaciers terminated on land is based on the research of Szafraniec [40].

Table 1. Landsat satellite scenes and digital elevation model (DEM) files used in the analysis including the source material used in Figure 2.

\begin{tabular}{|c|c|c|}
\hline \multicolumn{3}{|c|}{ Landsat 5 Thematic Mapper (TM) } \\
\hline No. & ID & Acquisition date \\
\hline 1 & LT52170031986220KIS00 & 08.08.1986 \\
\hline 2 & LT52080051990232KIS00 & 20.08 .1990 \\
\hline 3 & LT52170031985217KIS00 & 05.08 .1985 \\
\hline 4 & LT52130041992241KIS00 & 28.08 .1992 \\
\hline \multicolumn{3}{|c|}{ Landsat 8 Operational Land Imager/Thermal InfraRed Sensor (OLI/TIRS) } \\
\hline 5 & LC82200032017214LGN00 & 02.08 .2017 \\
\hline 6 & LC82080052014218LGN01 & 06.08 .2014 \\
\hline 7 & LC82150042017243LGN00 & 31.08 .2017 \\
\hline 8 & LC82160032016216LGN01 & 03.08 .2016 \\
\hline \multicolumn{3}{|c|}{ ArcticDEM $5 \mathrm{~m}$ and $10 \mathrm{~m}$ of resolution } \\
\hline No. & File name & Creation date (and source dates) \\
\hline 9 & 34_50_2_2_5m_v2.0_reg_dem & 07.12.2016 (2012-2015) \\
\hline 10 & 34_52_10m_v3.0_reg_dem & 23.07.2018 (2010-2017) \\
\hline 11 & 34_51_2_2_5m_v2.0_reg_dem & 08.12.2016 (2012-2015) \\
\hline 12 & 34_53_2_1_5m_v2.0_reg_dem & 07.12.2016 (2012-2015) \\
\hline 13 & 34_53_1_1_5m_v2.0_reg_dem & 07.12.2016 (2012-2015) \\
\hline 14 & 35_51_2_2_5m_v2.0_reg_dem & 10.12.2016 (2012-2015) \\
\hline 15 & 35_52_1_1_5m_v2.0_reg_dem & 08.12.2016 (2012-2015) \\
\hline
\end{tabular}


(a)

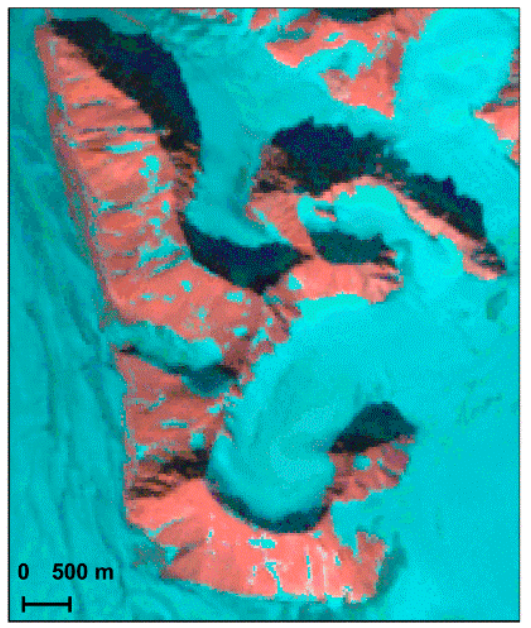

(c)

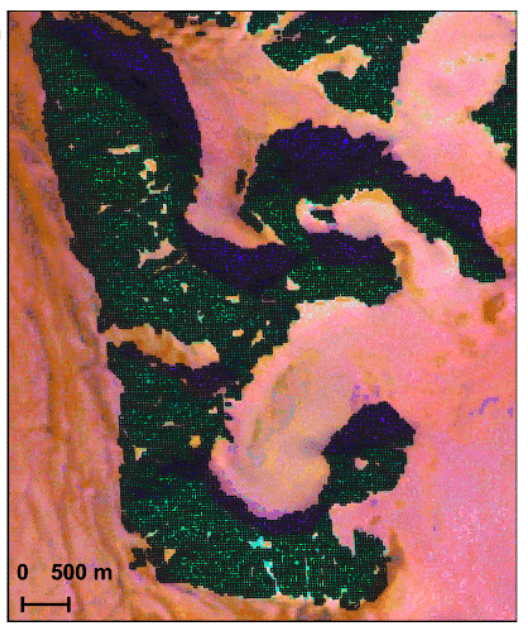

(b)

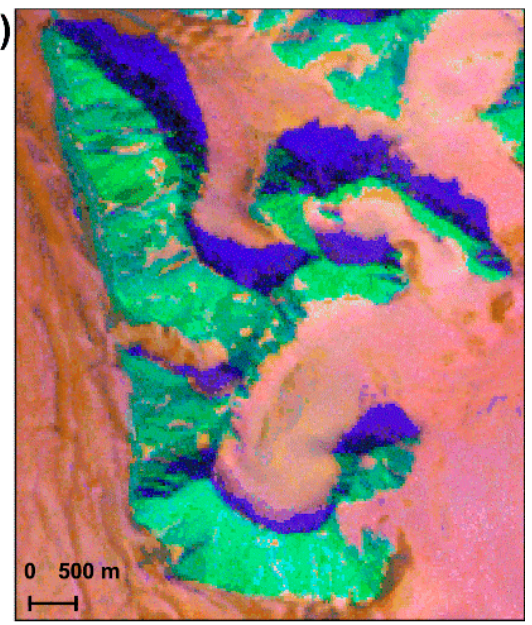

(d)

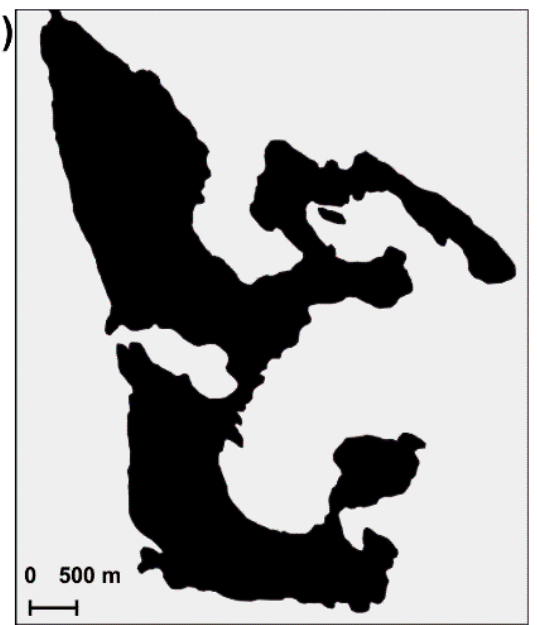

Figure 3. Identification of the glacier-nunatak border based on a Landsat satellite image (background based on the Landsat 5 scene ID: LT52170031986220KIS00, 8.08.1986, National Aeronautics and Space Administration (NASA) and U.S. Geological Survey (USGS)): (a) colour composition image based on the Landsat 5 TM 543 channels (and 654 for Landsat 8 OLI/TIRS) created using ArcGIS; (b) colour composition processing using Principal Components in ArcGIS; (c) raster to vector conversion using the red channel of the Principal Components in QGIS and extraction of DN < 130; (d) manual correction of the glacier-nunatak border in QGIS by removing the shaded parts of the glacier and moraine material on the ice and merge.

\section{Results}

\subsection{Characteristics of the Nunataks' Deglaciation Rate}

Seven nunataks from different parts of Spitsbergen which represent different altitude ranges (Table 2; Figure 4), were arbitrary selected as examples of the process studied: lower nunataks reaching 700-800 m a.s.l. in the southwestern part of the island, to thousanders in the North, East and central parts of Spitsbergen, and finally those reaching over $1300 \mathrm{~m}$ a.s.l. in the north-eastern parts. Examples from the western, southern and central parts of Spitsbergen, with slopes reaching altitudes associated to both accumulation and ablation zones of surrounding glaciers (equilibrium line altitude (ELA) of glaciers is on average at 350-500 $\mathrm{m}$ a.s.l. [41-43]), present a more normal-type of elevation distribution. Nunataks located in the northern and eastern parts, and indeed mostly within the accumulation zone, are more asymmetrical in their elevation distribution, mainly dominating the higher elevation ranges. Nunataks differ in their shape, both in the orientation of their main axis but also in relation 
to how compact they are. The most compact nunataks are characterized by the highest elevation of the nunatak-ice boundary (above ELA). The average nunatak area at the turn of the 1980s/90s was $5.17 \mathrm{~km}^{2}$, and increased by $14.7 \%$ to an average of $5.93 \mathrm{~km}^{2}$ to $2014-2017$. Nunataks at lowest altitudes from the southern and western parts experienced the largest changes, with an area increase of 26-29\%. The smallest changes were identified at high altitude nunataks from the eastern and north-eastern parts, with a change of $\pm 1-2 \%$.

Table 2. Selected nunataks from Spitsbergen and their characteristics.

\begin{tabular}{|c|c|c|c|c|c|c|}
\hline Region & $\begin{array}{l}\text { Nunatak } \\
\text { (Course of } \\
\text { Main Axis) }\end{array}$ & $\begin{array}{l}\mathrm{Z} \text { min.* } \\
{[\mathrm{m} \text { a.s.1.] }}\end{array}$ & $\begin{array}{c}\mathrm{Z} \text { max. } \\
{[\mathrm{m} \text { a.s.1.] }}\end{array}$ & $\begin{array}{l}\text { Z Mean } \\
\text { (Median) } \\
\text { [m a.s.l.] }\end{array}$ & $\begin{array}{c}\text { Area } \\
{\left[\mathrm{km}^{2}\right]}\end{array}$ & $\begin{array}{c}\text { Compactness } \\
\text { Coefficient }\end{array}$ \\
\hline \multirow{2}{*}{$\mathrm{N}$} & \multirow{2}{*}{$\begin{array}{l}\text { Schivefjellet } \\
(\mathrm{N}-\mathrm{S})\end{array}$} & 228 & \multirow{2}{*}{991} & $655 \pm 178(676)$ & 11.26 & 4.74 \\
\hline & & 228 & & $635 \pm 185(654)$ & 12.11 & 4.54 \\
\hline \multirow{2}{*}{ NE } & \multirow{2}{*}{$\begin{array}{c}\text { S Černyševfjellet } \\
(\mathrm{W}-\mathrm{E})\end{array}$} & 743 & \multirow{2}{*}{1352} & $1040 \pm 167(1043)$ & 3.61 & 2.43 \\
\hline & & 743 & & $1036 \pm 164$ (1038) & 3.55 & 2.35 \\
\hline \multirow{2}{*}{$\mathrm{E}$} & \multirow{2}{*}{$\begin{array}{c}\text { Malte Brunfjellet } \\
\text { (SW-NE) }\end{array}$} & 435 & \multirow{2}{*}{996} & $778 \pm 156(802)$ & 3.14 & 3.98 \\
\hline & & 435 & & $773 \pm 154(790)$ & 3.19 & 4.24 \\
\hline \multirow{2}{*}{$S$} & \multirow{2}{*}{$\begin{array}{l}\text { Pulkowofjella } \\
\text { (N-S) }\end{array}$} & 66 & \multirow{2}{*}{552} & $319 \pm 116(323)$ & 7.08 & 3.62 \\
\hline & & 63 & & $287 \pm 121(278)$ & 8.90 & 3.10 \\
\hline \multirow{2}{*}{ SW } & \multirow{2}{*}{$\begin{array}{l}\text { Kverven } \\
\text { (NW-SE) }\end{array}$} & 381 & \multirow{2}{*}{692} & $545 \pm 69(553)$ & 2.37 & 3.71 \\
\hline & & 372 & & $536 \pm 71(544)$ & 2.75 & 3.29 \\
\hline \multirow{2}{*}{ W } & \multirow{2}{*}{$\begin{array}{l}\text { Kaosfjellet } \\
(\mathrm{NW}-\mathrm{SE})\end{array}$} & 180 & \multirow{2}{*}{750} & $492 \pm 126(505)$ & 6.87 & 5.81 \\
\hline & & 180 & & $481 \pm 127(488)$ & 8.85 & 5.36 \\
\hline \multirow{2}{*}{ C } & \multirow{2}{*}{$\begin{array}{l}\text { Drøntoppen } \\
\text { (SW-NE) }\end{array}$} & 450 & \multirow{2}{*}{1021} & $769 \pm 136(784)$ & 1.89 & 2.29 \\
\hline & & 445 & & $737 \pm 150(746)$ & 2.16 & 2.16 \\
\hline
\end{tabular}

* the elevation of the glacier-nunatak border.

Average altitudes of nunataks have been experiencing considerable vertical changes between 1985-2017 as a result of the lowering of the boundary between the glacier and the nunatak, with those from the southern and central parts decreasing on average by more than $30 \mathrm{~m}$ over this period. On the other hand, nunataks at higher altitudes have experienced minimal changes between 1985 and 2017, with a mean elevation change of 4-5 m on average (which falls within the ArcticDEM vertical accuracy). This is the case for nunataks at mean elevation of approximately or above $400 \mathrm{~m}$ a.s.l., i.e., from the eastern and north-eastern parts (see Table 2).

\subsection{Spitsbergen Deglaciation Rate in the Vertical Profile Relative to the Slopes' Exposure}

The nunataks visible on images from 1985-1992 showed an asymmetrical surface area distribution in relation to the aspect of their slopes (Figure 5). Thus, most of the slopes (46-74\%) are south-facing (SW, S or SE exposures), whilst a small minority (2-12\%) present a NW-facing exposure. The nunatak surface increased on average by $0.6-1.2 \%$ between 1985-2017 for E-NE-N-facing slopes, at the expense of the share of slope area for other exposure, particularly south-facing slopes (changing on average $-0.9 \%$ ) (Figure 6). 

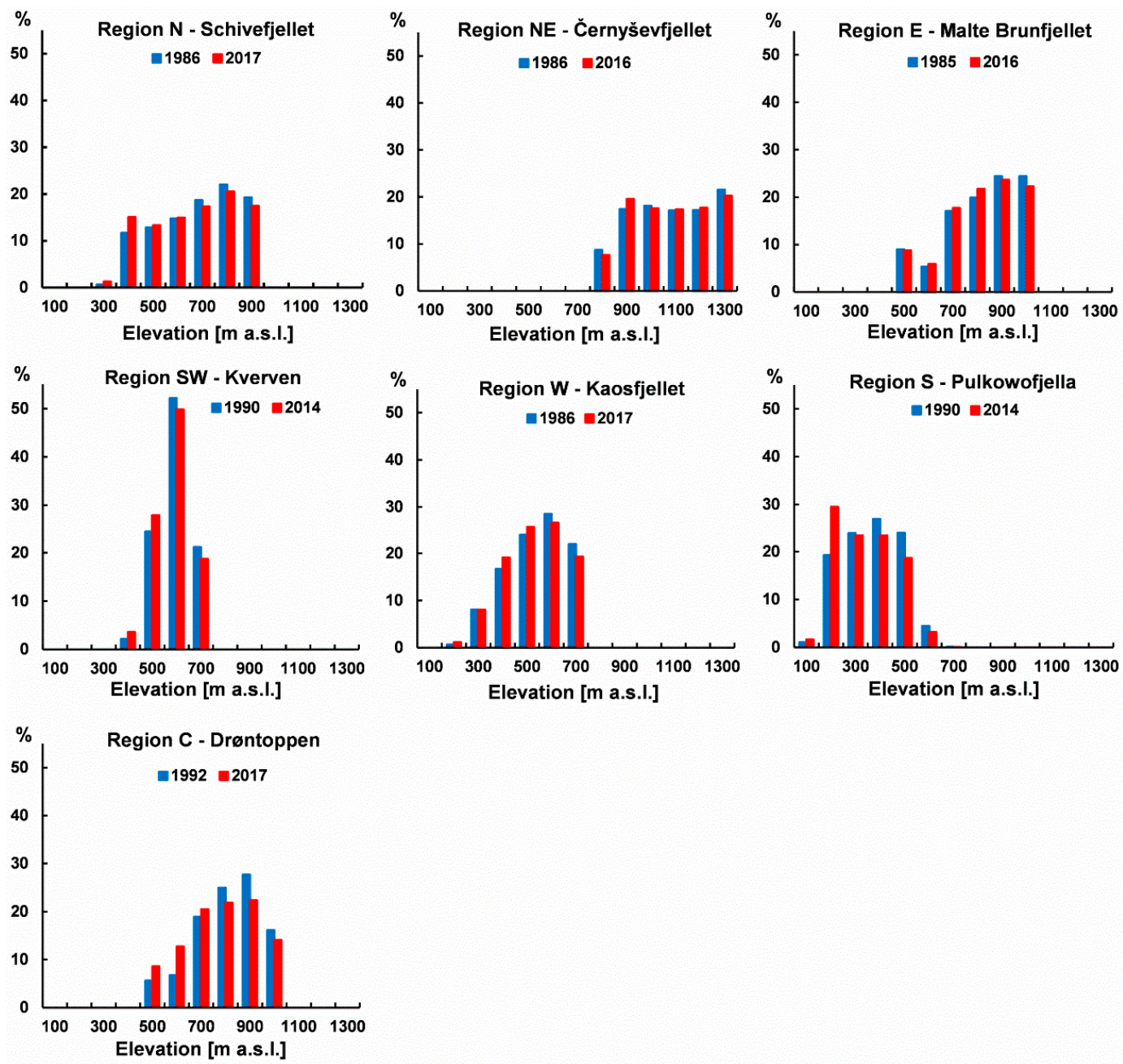

Figure 4. Histograms showing the distribution of nunataks surfaces in different elevation ranges.

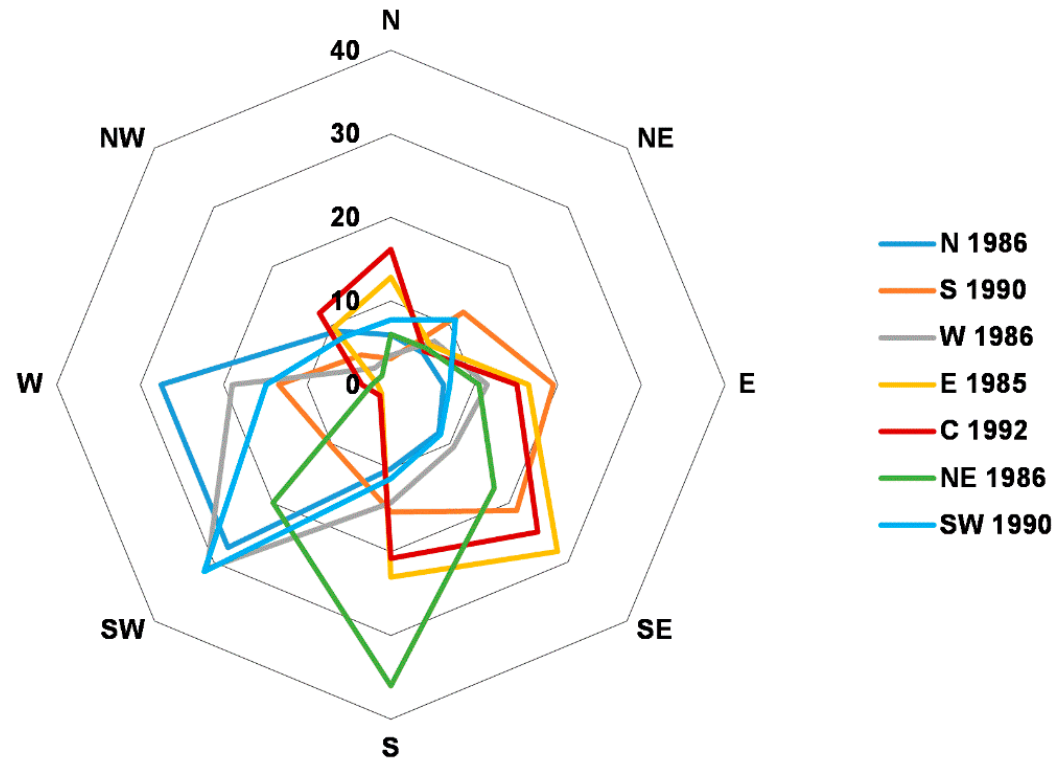

Figure 5. Percentage share of slope exposure for the nunataks visible on images from 1985-1992 in Spitsbergen. 


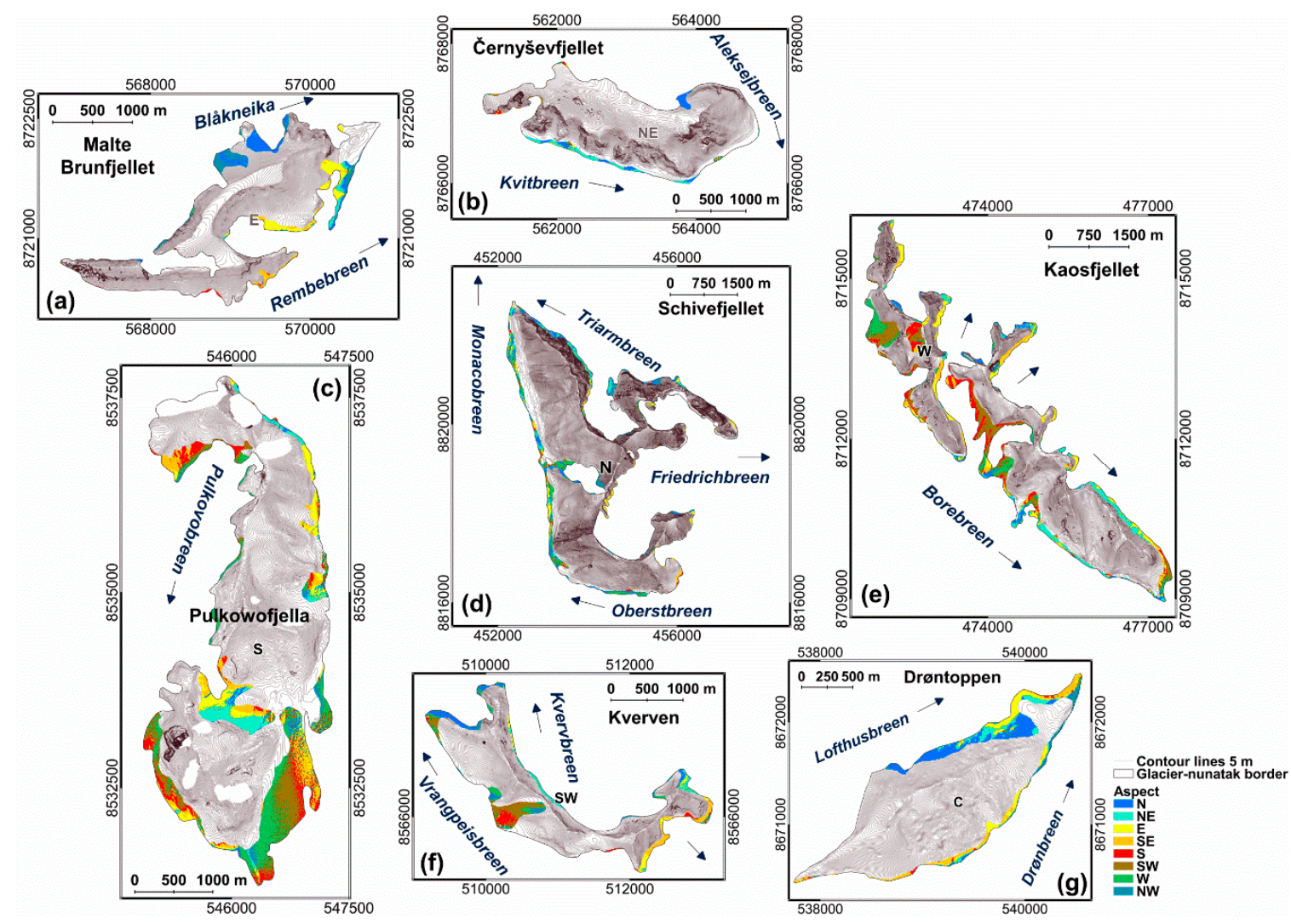

Figure 6. Changes observed from Spitsbergen nunataks area in relation to the aspect of their slopes in 1985-2017: (a) region E-Malte Brunfjellet; (b) region NE—southern part of Černyševfjellet; (c) region S-Pulkovofjella; (d) region N-Schivefjellet; (e) region W-Kaosfjellet; (f) region SW-Kverven; (g) region C-Drøntoppen (source of dense contour lines: ArcticDEM digital elevation model [35]); the arrows point to the glacier movement direction.

Considering the changes in the mean elevation of all nunataks in relation to the slope aspect, the smallest differences occur on the north-facing slopes and on those with E, SE and S exposures (Figure 7). It should be emphasized that the average altitude of south-facing slopes from the E, W and $\mathrm{NE}$ regions increased, according to negative value of the deglaciation rate of about $-0.3 \mathrm{~m} \mathrm{a}^{-1}$ during the study period. The biggest differences occurred in the western sectors (SW-W-NW), especially in the case of low-lying nunataks from the southern region, which emerged at a rate of $1.5 \mathrm{~m} \mathrm{a}^{-1}$. The tendency was the opposite for the highest-located nunatak from the NE region, with increasing slope mean altitude by up to $2.1 \mathrm{~m} \mathrm{a}^{-1}$ on the NW slopes. This is because of the location of Černyševfjellet mainly in the accumulation zone, where the main regulator was probably winter snowfall. Topography is also likely to play an important role in this case, as this nunatak is linked to several other ridges, forming a natural cirque conducive to accumulation.

Considering all the nunataks studied here, the deglaciation during the study period mainly influenced the northern and north-eastern slopes, reaching an average rate of decrease of $1.2 \mathrm{~m} \mathrm{a}^{-1}$ (Figure 8). Southern slopes showed the slowest rate of deglaciation, reaching an average of $0.2 \mathrm{~m} \mathrm{a}^{-1}$ decrease in mean elevation. 


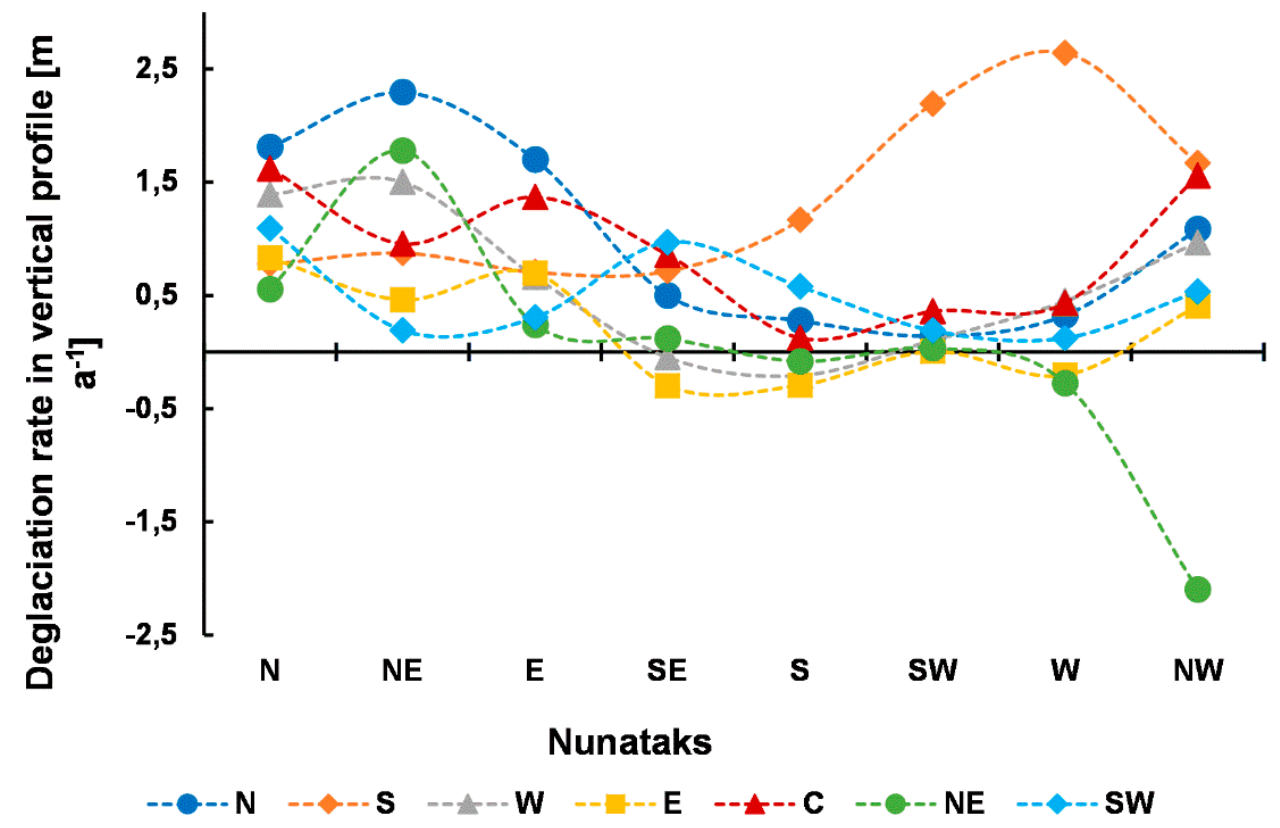

Figure 7. Average rate of change for the mean nunatak elevation on Spitsbergen in relation to slope exposure.

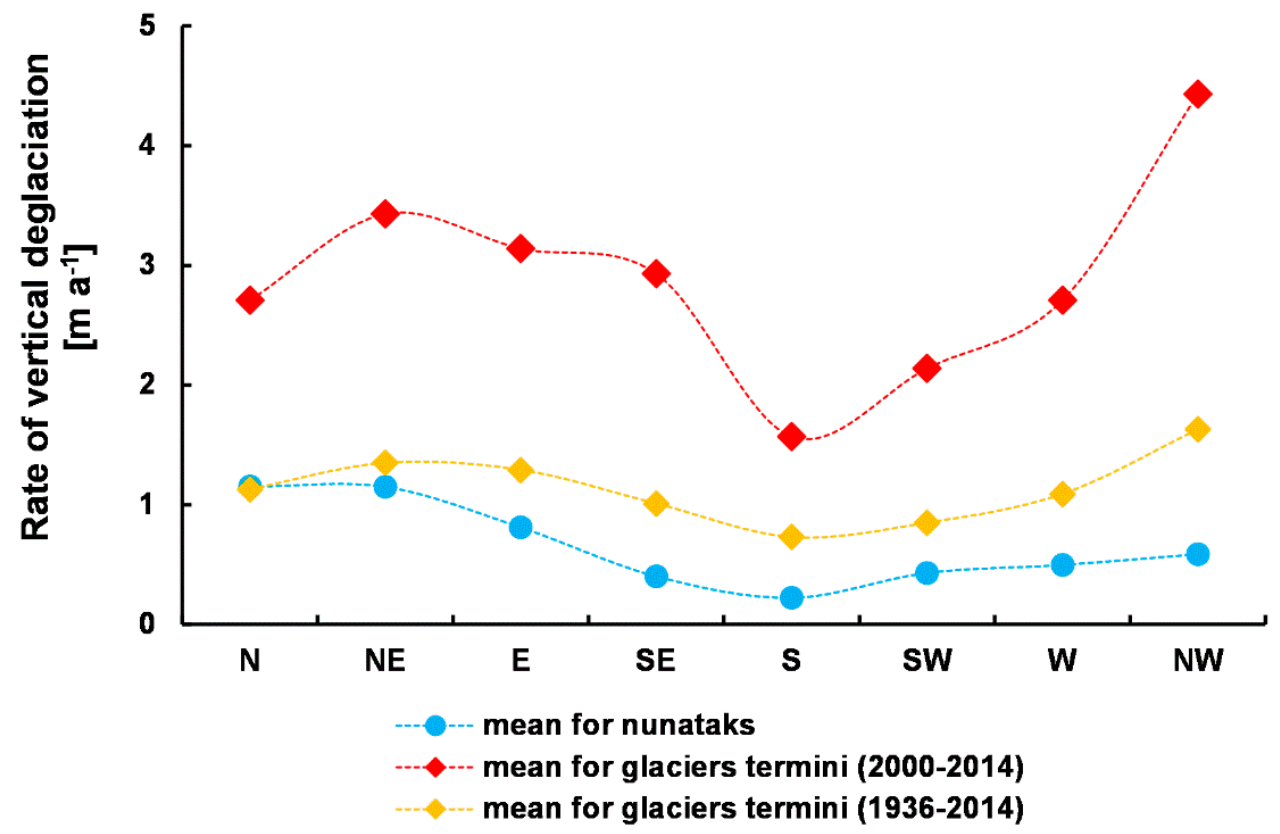

Figure 8. Average rate of relative decrease of the mean nunatak elevation in relation to the slope exposure for the 1985-2017 period, in comparison with the average rate of increase of the termini altitude of glaciers terminating on land (1936-2014 and 2000-2014 periods, based on data in Szafraniec [40]).

The rate of vertical deglaciation of the nunataks in relation to the aspect of their slopes correlates well with the rate of changes of the termini altitude of Spitsbergen glaciers ending on land (see Figure 8) [40]. However, the maximum rate of exposure of nunataks applies to north-facing slopes, which has increased over the 21st century.

The data were standardized for the average rate of deglaciation on Spitsbergen in the vertical profile per degree decrease in altitude. For the average altitude of the analysed nunataks, i.e., $641 \mathrm{~m}$ a.s.l. for the years 1985-2017, the rate of slope uncovering from under the glacier is $0.06 \mathrm{~m} \mathrm{a}^{-1}$ per degree 
of terrain slope (Figure 9). In turn, at the average minimum altitude for Spitsbergen glaciers termini, i.e., ca. $280 \mathrm{~m}$ a.s.l. in 2014 (based on the data calculated by Szafraniec [40]), the rate of vertical deglaciation is on average approximately $0.4 \mathrm{~m} \mathrm{a}^{-1}$ per one degree of slope. South and west nunataks with the lowest mean altitude, protruded from the ice by 0.13 and $0.11 \mathrm{~m} \mathrm{a}^{-1}$ per degree of terrain slope, respectively. The nunatak from the E region, on the other hand, changes at a rate of $0.005 \mathrm{~m} \mathrm{a}^{-1}$ per degree of terrain slope. Only the NE nunatak, the highest of all, decreased in size (i.e., became increasingly covered by ice/snow) at an average rate of $-0.005 \mathrm{~m} \mathrm{a}^{-1}$ per degree of terrain slope.

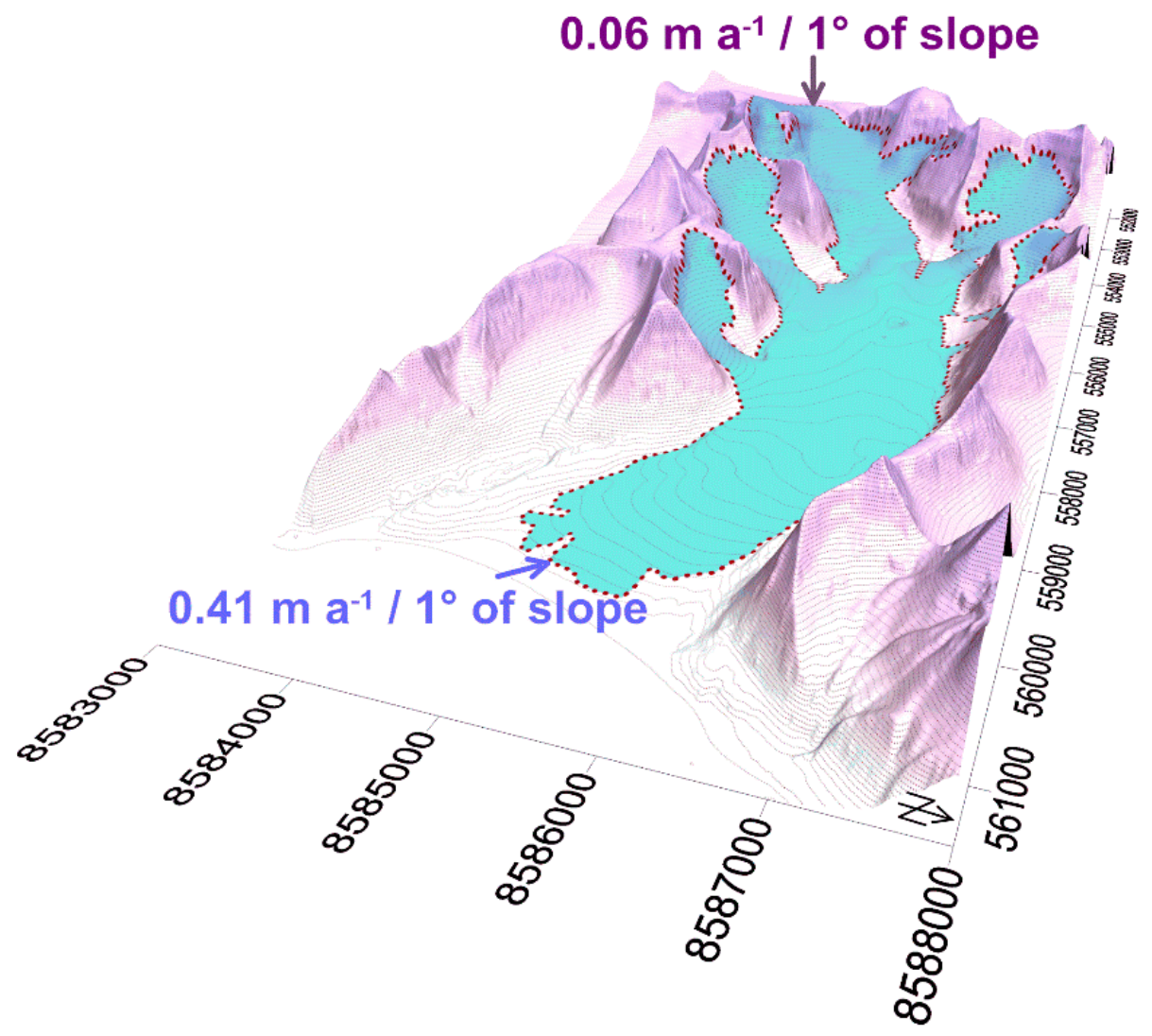

Figure 9. Model of the average rate of deglaciation for Spitsbergen in the vertical profile converted to degrees of terrain slope (source of the Anna Margrethebreen DEM: [35]).

\subsection{Expansion of the Periglacial Zone on Spitsbergen in a Vertical Profile}

An analysis of the changes in the nunatak areas between 1985 and 2017 shows that expansion of the periglacial zone depends both on the slope exposure and the altitude of the nunataks. The higher the elevation, the smaller the increase in slope area, especially for south-facing nunataks. The average rate of deglaciation was also calculated here to ultimately estimate the rate of expansion of the periglacial zone from the top of the glacier for selected altitude levels. Spitsbergen nunataks are very diverse in this respect (Figure 10). However, they all have in common a clear maximum deglaciation rate which relates to the average nunatak altitude. Thus, lower nunataks show the highest maximum deglaciation rates. This value decreases with the glacial altitude down to ca. 500-3000 $\mathrm{m}^{2} \mathrm{a}^{-1}$, probably due to shading, low level clouds entering the valleys and persistent fogs (such conditions occur, for example, in Hornsund for approximately $10 \%$ of the year [44]). It also decreases up the glacier, where it can even reach a situation of inversion associated with an air temperature gradient and the processes within the accumulation zone (e.g., snow blowing, avalanche supply). 


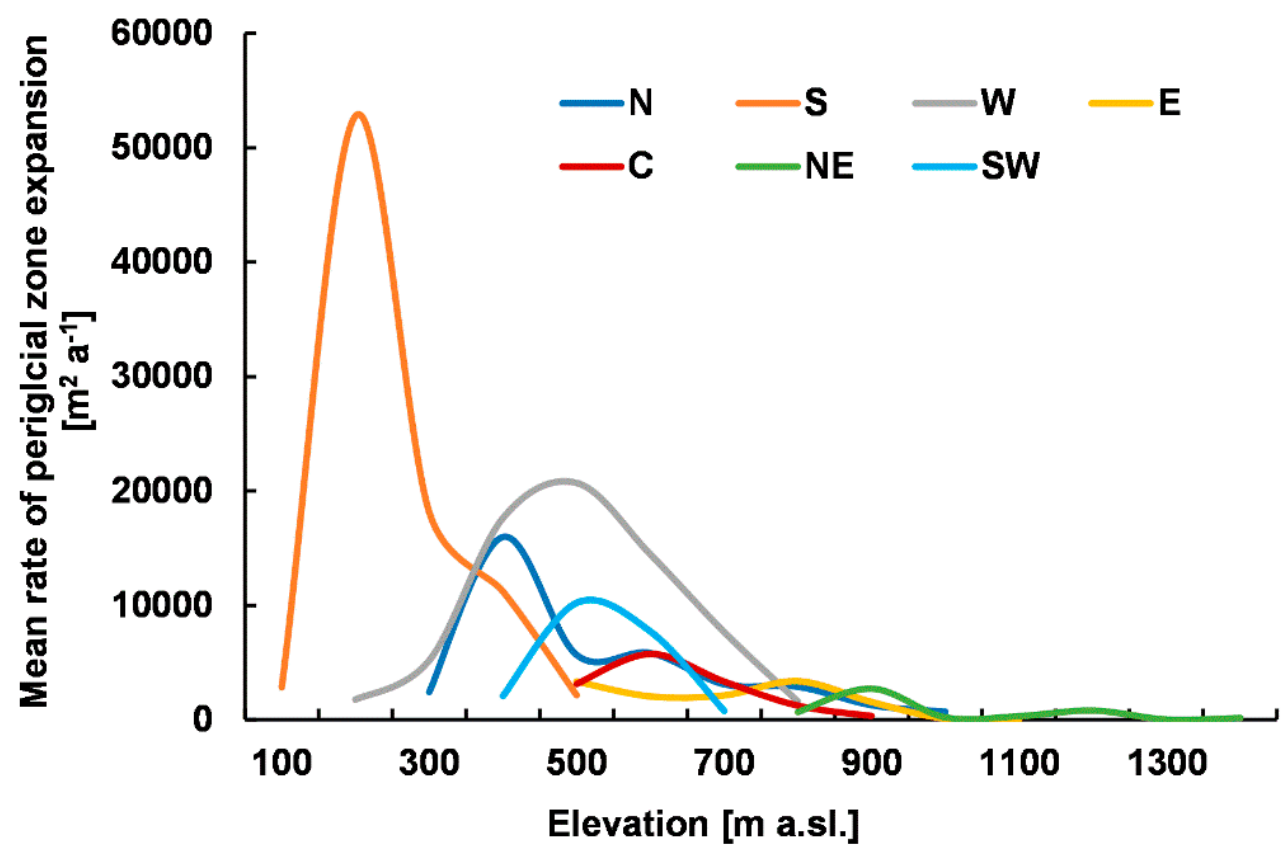

Figure 10. Rate of surface deglaciation along a vertical profile for the analysed Spitsbergen nunataks.

The maximum surface deglaciation rates along a vertical profile have been compared with the mean elevation for Spitsbergen nunataks (Figure 11). These two variables relate in an exponential way to some extent and this relation is significant at a 0.05 level. This suggests that for a mean nunatak altitude of $640 \mathrm{~m}$ a.s.l. the maximum surface deglaciation rate can reach 10,000 $\mathrm{m}^{2} \mathrm{a}^{-1}$. To check how solid is this relationship, the sample size must be larger and, therefore, more examples in terms of geographical location, altitude and the course of the main axis of the nunatak are required.

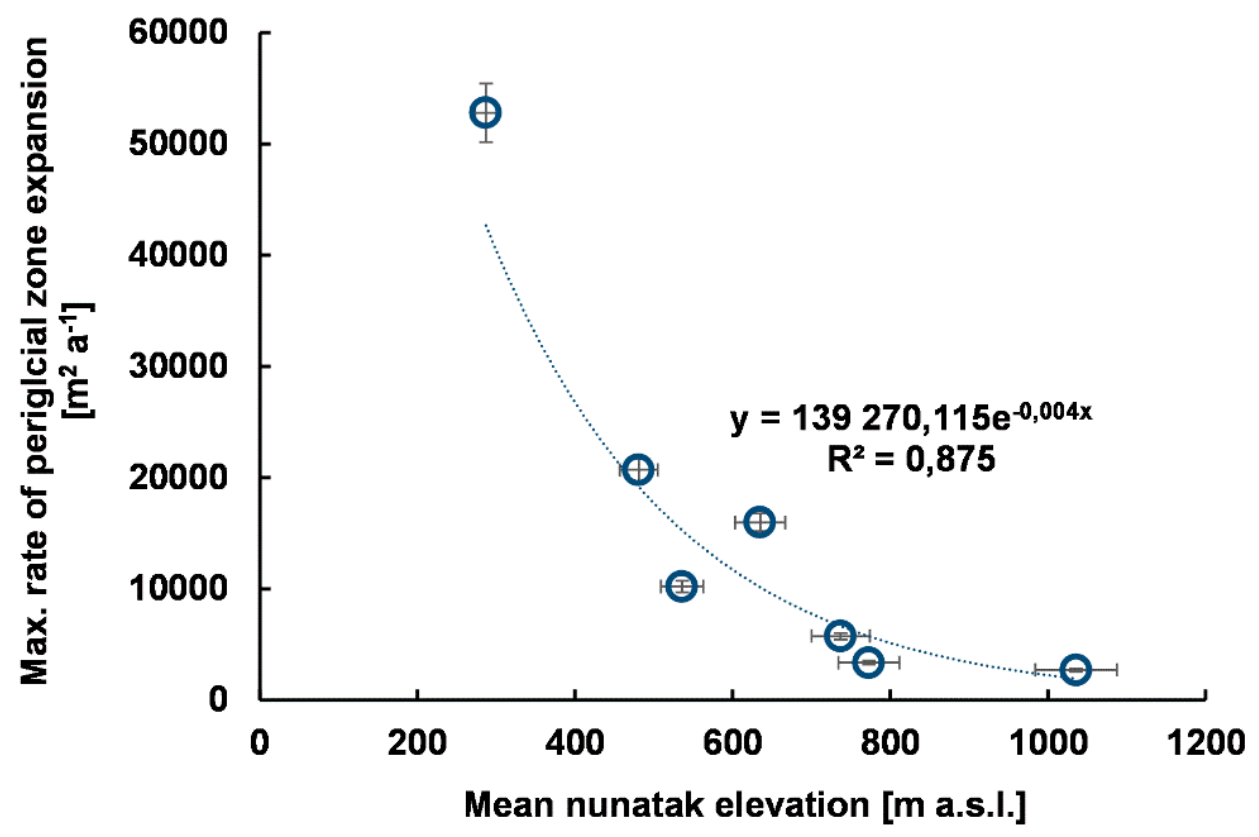

Figure 11. Statistical relationship between the maximum surface deglaciation rate for the selected nunataks in Spitsbergen and their mean elevation.

The increased slope exposure also leads to changes in the slope relief due to increased weathering and paraglacial processes. High-resolution aerial photographs (available on the TopoSvalbard portal) 
show rock avalanche pathways and screes below the nunataks, clearly visible especially on their northern slopes. Rock material is also incorporated and transported down the valleys through a system of lateral and middle glacier moraines. In addition, supraglacial-marginal lakes form between the slopes of the nunataks and the glacier, as is the case of Černyševfjellet. In this case, melt water accumulates on its south-east facing base at an altitude of ca. $700 \mathrm{~m}$ a.s.l. also affecting the thermal conditions of the surrounding environment.

\section{Discussion}

The results described here follow recent observations of glacier surface lowering in Svalbard due to global warming. This phenomenon is more intense for the lower glacier sections [45-51]. This is associated with a possible expansion of the periglacial zone at high altitudes, from the top of ridges and nunataks down the slopes. However, this process would be temporarily stopped by the phenomenon of the glacier surge typically observed in Svalbard [52]. This phenomenon is controlled through the accumulation of snow in the reservoir zone and ice-cliffs enthalpy on tidewater glaciers [53,54]. Glacier surge contributes to the spread of ice mass in an accelerated cycle, which locally may cause the glacier surface to rise and fall [55] (downwards movement of the glacier bulge [56]), and thus temporarily raising/lowering the nunatak-glacier border. The nunataks in this study occur above surging glaciers (e.g., Monacobreen with the active phase of the glacier surge in 1990-1992 [57] and 1993-1995 [58], Hinlopenbreen in 1969-1972 [59], Negribreen in 1935-1936 [59], and since 2018, observed on satellite scenes, Au Torellbreen in 1990 and 2007 [56]).

The traditionally understood periglacial zone is defined as the area encompassed by cold climate, with intense frost action, located in front of a glacier/ice sheet [60,61]; however, this term has evolved over time [62], to include area with geomorphic processes and landforms of cold non-glaciated landscapes irrespective of their relationship with ice sheets or glaciers [63]. These areas are usually under the influence of frost and the presence of permafrost. Recently deglaciated slopes are too unstable to bear imprints of periglacial modification. However conditions typical for a periglacial zone in its classical sense are fulfilled in the upper parts of the nunatak on Iceland [64]. During the Pleistocene glaciations, most of the land was entirely covered by ice, with little presence of periglacial zones at this latitude, particularly for the glacier/ice-cap accumulation zones. In addition, the cover-type of glaciation experienced in Svalbard makes it nearly impossible to distinguish any "upper periglacial zone". However, upper periglacial areas are now visible as the glaciers shrink, with the newly exposed deglaciated areas now meeting all the criteria for the periglacial zone. Small valley glaciers on Svalbard were thicker and more extensive during the Little Ice Age (LIA). Since this period, small glaciers have been increasingly becoming frozen to their beds. They have been also experiencing a long-term negative mass balance, leading to the ongoing thermal transition from polythermal to cold-based regimes [65]. The decrease in their volume due to recession leads to an increased penetration of negative air temperatures, leading to a deeper occurrence of the cold-temperate transition surface (CTS) inside polythermal glaciers [66,67]. In extreme cases, this surface lowers to such extent that the entire glacier shifts from polythermal to cold. At this stage, the CTS surface becomes the permafrost base (PB) surface, as noted by Dobiński et al. [12,13,68] and Etzelmüller and Hagen [69]: "from a purely thermal point of view at least, glacier ice at sub-pressure melting point temperatures would become a part of the permafrost environment, and thin glaciers in Arctic or high altitude regions with the border of mountain permafrost altitude well below the glacier terminus are often entirely cold-based". Dobiński [5] presents a similar classification. Therefore, concerning the origin of the ground-ice/permafrost, it can be assumed that permafrost inherited from beneath cold surface ice and newly formed permafrost developed since the disappearance of the temperate surface ice can coexist. Thus, permafrost evolution is influenced by the thermal regime of the glacier formerly covering the ground [70].

Periglacial and permafrost studies on glacial forefields differ on their characteristics because a close coexistence of ice of different genetic origins can be observed in mountain glacier forefields, with the permafrost in these areas varying in age from several years to a few thousands years [71]. There is 
also geomorphological and geophysical evidence for permafrost aggradation on glacial forefields [72]. In cold mountains, polythermal glaciers and permafrost often coexist in close proximity (among others, due to the naled-ice phenomenon as described by Baranowski [73] and studied by Bukowska-Jania and Szafraniec [74]), particularly in areas where the climatic conditions are in transition from wet-maritime to dry-continental regimes. Under such conditions, glaciers show a regional decrease in size often accompanied by an increase in the occurrence of discontinuous permafrost and other related periglacial and glacial landforms, such as rock glaciers and push moraines [75]. Perennially frozen ground in areas deglaciated since the Little Ice Age may represent either formerly subglacial permafrost, preserved or developed under the cold ice surface, or permafrost newly formed since the disappearance of the temperate surface ice [70]. An analogous process must occur in nunatak periglacial zone above glaciers.

However, recognizing the presence and evolution of the periglacial environment in the nunataks' areas and linking it to the existence and evolution of permafrost is a pioneering proposition in the description and understanding of the glacier-permafrost interaction. There are very few papers dealing with the issue of nunataks' deglaciation at all $[76,77]$.

Periglacial environments on ridge tops and nunataks present different characteristics. Rock ridges and slopes emerging from the ice increasingly experience freeze-thaw processes consequently disintegrating and producing weathering material [15]. Moreover, the rock slopes released from the ice are subjected to a greater degree of penetration of negative air temperatures, lower at these elevations than in coastal areas. The disappearance of unconstrained glaciation (ice caps and ice fields) and glacier surface lowering therefore intensifies permafrost aggradation.

\section{Conclusions}

Contemporary climate warming is not only causing the retreat of glacier fronts, but also a decrease in thickness of the glaciers.

Exposed rock surfaces thus experience much more severe climatic conditions than if covered under the ice. The amplitude of daily and seasonal temperatures on the exposed surface is higher, and the average annual air temperature is lower as a consequence. Temperature variations can cause increased weathering of the slope material, while exposure to temperatures less than $-1{ }^{\circ} \mathrm{C}$ leads to the permafrost aggradation on the slopes and forefield surrounding the glacier. This aggradation is the most intense on north-facing slopes as well as on rock walls with the nunatak-ice boundary lowered to the ablation zone of surrounding glaciers (e.g., in the southern part of Spitsbergen). The process is slower on south-facing slopes and on highest elevated nunataks (examples located in E, C and NE regions). It changes with the inclination of the terrain at a rate of $0.06 \mathrm{~m} \mathrm{a}^{-1}$ per degree of the terrain slope, for an average elevation of approximately $640 \mathrm{~m}$ a.s.l (average for studied cases). The maximum rate of surface deglaciation measured here reached ca. 10,000 $\mathrm{m}^{2} \mathrm{a}^{-1}$. Consequently, upper glacial recession leads to expansion of the periglacial environment and its associated processes.

Glaciers in Svalbard that reduce their thickness also change their thermal characteristics, mainly transitioning from polythermal to cold glaciers frozen to their beds. This completely changes the nature of the glacier movement by eliminating the bottom slide motion, also forces permafrost aggradation under the glacier.

In cold climates with a MAAT $<0{ }^{\circ} \mathrm{C}$, deglaciation occurs as a result of warming or a reduction of snow accumulation, with the area abandoned by the glacier becoming occupied by active periglacial environments accompanied by permafrost aggradation. Therefore, both glacial and periglacial environments are changing over time and concomitantly. While glaciers are receding, the surrounding newly exposed areas shows favourable conditions for permafrost aggradation. This occurs not only at the glacier front, but also along their sides for climates with a MAAT $<-1{ }^{\circ} \mathrm{C}$.

Author Contributions: Conceptualization, W.D.; methodology, J.E.S.; writing-original draft preparation, W.D. and J.E.S.; supervision, W.D.; visualization, J.E.S. All authors have read and agreed to the published version of the manuscript.

Funding: This research received no external funding. 
Acknowledgments: Authors gratefully thank the reviewers for critical review of the manuscript.

Conflicts of Interest: The authors declare no conflict of interest.

\section{References}

1. Washburn, A.L. Periglacial Processes and Environments; Edward Arnold: London, UK, 1973.

2. French, H.M. The Periglacial Environment, 3rd ed.; John Wiley and Sons Ltd.: Chichester, UK, 2007.

3. Black, R.F. Permafrost: A review. Geol. Soc. Am. Bull. 1954, 65, 839-856. [CrossRef]

4. Dobiński, W. Permafrost. Earth Sci. Rev. 2011, 108, 158-169. [CrossRef]

5. Dobiński, W. The Cryosphere and Glacial Permafrost as Its Integral Component. Open Geosci. 2012, 4, 623-640. [CrossRef]

6. Van Everdingen, R.O. Multi-Language Glossary of Permafrost and Related Ground-Ice Terms. Definitions. 1998. Available online: http://globalcryospherewatch.org/reference/glossary_docs/Glossary_of_Permafrost_ and_Ground-Ice_IPA_2005.pdf (accessed on 22 February 2020).

7. Haeberli, W.; Hallet, B.; Arenson, L.; Elconin, R.; Humlum, O.; Kääb, A.; Kaufmann, V.; Ladanyi, B.; Matsuoka, N.; Springman, S.; et al. Permafrost Creep and Rock Glaciers Dynamics. Permafr. Periglac. Process. 2006, 17, 189-214. [CrossRef]

8. Benn, D.I.; Evans, D.J.A. Glaciers and Glaciation; Arnold: London, UK, 1998.

9. Paterson, W.S.B. The Physics of Glaciers, 2nd ed.; Pergamon Press: Oxford, UK, 1981.

10. Jahn, A. Problems of the Periglacial Zone; PWN: Warszawa, Poland, 1975.

11. Karte, J.; Liedtke, H. The theoretical and practical definition of the term "periglacial" in its geographical and geological meaning. Biul. Peryglac. 1981, 28, 123-135.

12. Dobiński, W.; Grabiec, M.; Gądek, B. Spatial relationship in interaction between glacier and permafrost in different mountainous environments of high and mid latitudes, based on GPR research. Geol. Q. 2011, 55, 375-388.

13. Dobiński, W.; Grabiec, M.; Glazer, M. Cold-temperate transition surface and permafrost base (CTS-PB) as an environmental axis in glacier-permafrost relationship, based on research carried out on the Storglaciären and its forefield, northern Sweden. Quat. Res. 2017, 88, 551-569. [CrossRef]

14. Harris, C.; Murton, J.B. (Eds.) Cryospheric Systems: Glaciers and Permafrost; Special Publications; Geological Society: London, UK, 2005; p. 242.

15. Humlum, O. Holocene permafrost aggradation in Svalbard. In Cryospheric Systems: Glaciers and Permafrost; Harris, C., Murton, J.B., Eds.; Special Publications; Geological Society: London, UK, 2005; Volume 242, pp. 119-130.

16. Waller, R.I. The influence of basal processes on the dynamic behaviour of cold-based glaciers. Quartern. Int. 2001, 86, 117-128. [CrossRef]

17. Waller, R.I.; Tuckwell, G.W. Glacier-permafrost interactions and glaciotectonic landform generation at the margin of the Leverett Glacier, West Greenland. In Cryospheric Systems: Glaciers and Permafrost; Harris, C., Murton, J.B., Eds.; Special Publications; Geological Society: London, UK, 2005; Volume 242, pp. 39-51.

18. Dabski, M. Should Glaciers Be Considered Permafrost? Geoscience 2019, 9, 517. [CrossRef]

19. Hagen, J.O.; Liestøl, O.; Roland, E.; Jørgensen, T. Glacier Atlas of Svalbard and Jan Mayen; Meddelelser 129: Oslo, Norway, 1993.

20. Humlum, O.; Instanes, A.; Sollid, J.L. Permafrost in Svalbard: A review of research history, climatic background and engineering challenges. Polar Res. 2003, 22, 191-215. [CrossRef]

21. Harada, K.; Yoshikawa, K. Permafrost thickness at Moskuslagoon, Spitsbergen. In Proceedings of the Seventh International Conference on Permafrost, Yellowknife, NT, Canada, 23-27 June 1998; Volume 55, pp. 427-431.

22. Landvik, J.Y.; Mangerud, J.; Salvigsen, O. Glacial history and permafrost in the Svalbard area. In Proceedings of the 5th International Conference on Permafrost, Trondheim, Norway, 2-5 August 1988; Senneset, K., Ed.; Tapir publishers: Trondheim, Norway, 1988; Volume 1, pp. 194-198.

23. Weertman, J. Effect of a basal water layer on the dimensions of ice sheets. J. Glaciol. 1966, 6, $191-207$. [CrossRef]

24. Isaksen, K.; Nordli, Ø.; Førland, E.J.; Łupikasza, E.; Eastwood, S.; Niedźwiedź, T. Recent warming on Spitsbergen-Influence of atmospheric circulation and sea ice cover. J. Geophys. Res. Atmos. 2016, 121, 11913-11931. [CrossRef] 
25. Kasprzak, M. High-resolution electrical resistivity tomography applied to patterned ground, Wedel Jarlsberg Land, south-west Spitsbergen. Polar Res. 2015, 34, 25678. [CrossRef]

26. Kasprzak, M.; Strzelecki, M.C.; Traczyk, A.; Kondracka, M.; Lim, M.; Migała, K. On the potential for a bottom active layer below coastal permafrost: The impact of seawater on permafrost degradation imaged by electrical resistivity tomography (Hornsund, SW Spitsbergen). Geomorphology 2017, 293, 347-359. [CrossRef]

27. Glazer, M.; Dobiński, W.; Marciniak, A.; Majdański, M.; Błaszczyk, M. Spatial distribution and controls of permafrost development in non-glacial Arctic catchment over the Holocene, Fuglebekken, SW Spitsbergen. Geomorphology 2020, 358, 107128. [CrossRef]

28. Nordli, Ø.; Przybylak, R.; Ogilvie, A.E.J.; Isaksen, K. Long-term temperature trends and variability on Spitsbergen: The extended Svalbard Airport temperature series, 1898-2012. Polar Res. 2014, 33, 21349. [CrossRef]

29. Isaksen, K.; Holmlund, P.; Sollid, J.L. Three deep Alpine-permafrost boreholes in Svalbard and Scandinavia. Permafr. Periglac. Process. 2001, 12, 13-25. [CrossRef]

30. Nilsen, N.I. Atmosfærisk Ising og Temperaturgradienter på Svalbard, Relatert Til Storstilt Værsituasjon. Master's Thesis, University of Bergen and University Courses, Svalbard, Norway, 1997.

31. Hauber, E.; Reiss, D.; Ulrich, M.; Preusker, F.; Trauthan, F.; Zanetti, M.; Hiesinger, H.; Jaumann, R.; Johansson, L.; Johnsson, A.; et al. Periglacial landscapes on Svalbard: Terrestrial analogs for cold-climate landforms on Mars. Geol. Soc. Am. Bull. 2011, 483, 177-201. [CrossRef]

32. Osuch, M.; Wawrzyniak, T. Climate projections in the Hornsund area, Southern Spitsbergen. Pol. Polar Res. 2016, 37, 379-402. [CrossRef]

33. Norwegian Meteorological Institute. Air Temperature in Svalbard, Annual Mean. Environmental Monitoring of Svalbard and Jan Mayen (MOSJ). Available online: http://www.mosj.no/en/climate/atmosphere/ temperature-precipitation.html (accessed on 12 May 2020).

34. EarthExplorer. Available online: https://earthexplorer.usgs.gov/ (accessed on 23 February 2020).

35. Porter, C.; Morin, P.; Howat, I.; Noh, M.-J.; Bates, B.; Peterman, K.; Keesey, S.; Schlenk, M.; Gardiner, J.; Tomko, K.; et al. ArcticDEM, Harvard Dataverse, V1. 2018. Available online: https://www.pgc.umn.edu/ data/arcticdem/ (accessed on 23 February 2020). [CrossRef]

36. ArcticDEM Data Description. Available online: https://www.pgc.umn.edu/guides/arcticdem/datadescription/ (accessed on 23 February 2020).

37. Morin, P.; Porter, C.; Cloutier, M.; Howat, I.; Noh, M.-J.; Willis, M.; Bates, B.; Willamson, C.; Peterman, K. ArcticDEM; A Publically Available, High Resolution Elevation Model of the Arctic. Geophys. Res. Abstracts 2016, 18, EGU2016-8396.

38. Glennie, C. Arctic High-Resolution Elevation Models: Accuracy in Sloped and Vegetated Terrain. J. Surv. Eng. 2018, 144. [CrossRef]

39. Murffit, J.; Duguay, C.R. Assessing the Performance of Methods for Monitoring Ice Phenology of the World's Largest High Arctic Lake Using High-Density Time Series Analysis of Sentinel-1 Data. Remote Sens. 2020, 12, 382. [CrossRef]

40. Szafraniec, J.E. Deglaciation rate on southern and western Spitsbergen in the conditions of Arctic amplification. Pol. Polar Res. 2018, 39, 77-98. [CrossRef]

41. Aas, K.S.; Dunse, T.; Collier, E.; Schuler, T.V.; Berntsen, T.K.; Kohler, J.; Luks, B. The climatic mass balance of Svalbard glaciers: A 10-year simulation with a coupled atmosphere-glacier mass balance model. Cryosphere 2016, 10, 1089-1104. [CrossRef]

42. Uszczyk, A.; Grabiec, M.; Laska, M.; Kuhn, M.; Igntiuk, D. Importance of snow as component of surface mass balance of Arctic glacier (Hansbreen, southern Spitsbergen). Pol. Polar Res. 2019, 40, 311-338. [CrossRef]

43. Małecki, J. Accelerating retreat and high-elevation thinning of glaciers in central Spitsbergen. Cryosphere 2016, 10, 1317-1329. [CrossRef]

44. Łupikasza, E.; Niedźwiedź, T. Circulation conditions favouring fog and low visibility occurrence in Hornsund (Spitsbergen). Probl. Klimatol. Polarn. 2016, 26, 5-12.

45. Ignatiuk, D.; Piechota, A.; Ciepły, M.; Luks, B. Changes of Altitudinal Zones of Werenskiodbreen and Hansbreen in Period 1990-2008, Svalbard. In Proceedings of the International Conference of Computational Methods in Sciences and Engineering 2014 (ICCMSE 2014), Athens, Greece, 4-7 April 2014; pp. 275-280. [CrossRef] 
46. Kohler, J.; James, T.D.; Murray, T.; Nuth, C.; Brandt, O.; Barrand, N.E.; Aas, H.F.; Luckman, A. Acceleration in thinning rate on western Svalbard glaciers. Geophys. Res. Lett. 2007, 34. [CrossRef]

47. Schäfer, M.; Möller, M.; Zwinger, T.; Moore, J.C. Dynamic modelling of future glacier changes: Mass-balance/ elevation feedback in projections for the Vestfonna ice cap, Nordaustlandet, Svalbard. J. Glaciol. 2015, 61, 1121-1136. [CrossRef]

48. Ziaja, W. Glacial Recession in Sørkappland and Central Nordenskiöldland, Spitsbergen, Svalbard, during the 20th Century. Arct. Antarct. Alp. Res. 2001, 33, 36-41. [CrossRef]

49. Ziaja, W. Response of the Nordenskiöld Land (Spitsbergen) glaciers Grumantbreen, Håbergbreen and Dryadbreen to the climate warming after the Little Ice Age. Ann. Glaciol. 2005, 42, 189-194. [CrossRef]

50. Ziaja, W.; Ostafin, K. Landscape-seascape dynamics in the isthmus between Sørkapp Land and the rest of the Spitsbergen: Will a new big Arctic island form? Ambio 2015, 44, 332-342. [CrossRef] [PubMed]

51. Ziaja, W.; Dudek, J.; Ostafin, K. Landscape transformation under the Gåsbreen glacier recession since 1899, southwestern Spitsbergen. Pol. Polar Res. 2016, 37, 155-172. [CrossRef]

52. Sevestre, H.; Benn, D.I. Climatic and geometric controls on the global distribution of surge-type glaciers: Implications for a unifying model of surging. J. Glaciol. 2015, 61, 646-662. [CrossRef]

53. Aschwanden, A.; Bueler, E.; Khroulev, C.; Blatter, H. An enthalpy formulation for glaciers and ice sheets. J. Glaciol. 2012, 58, 441-457. [CrossRef]

54. Sevestre, H.; Benn, D.I.; Luckman, A.; Nuth, C.; Kohler, J.; Lindbäck, K.; Pettersson, R. Tidewater Glacier Surges Initiated at the Terminus. J. Geophys. Res. Earth Surf. 2017, 123, 1035-1051. [CrossRef]

55. Hagen, J.O.; Eiken, T.; Kohler, J.; Melvold, K. Geometry changes on Svalbard glaciers: Mass-balance or dynamic response? Ann. Glaciol. 2005, 42, 255-261. [CrossRef]

56. Sund, M.; Eiken, T.; Hagen, J.O.; Kääb, A. Svalbard surge dynamics derived from geometric changes. Ann. Glaciol. 2009, 50, 50-60. [CrossRef]

57. Murray, T.; Strozzi, T.; Luckman, A.; Jiskoot, H.; Christakos, P. Is there a single surge mechanism? Contrasts in dynamics between glacier surges in Svalbard and other regions. J. Geophys. Res. 2003, 108. [CrossRef]

58. Mansell, D.; Luckman, A.; Murray, T. Dynamics of tidewater surge-type glaciers in northwest Svalbard. J. Glaciol. 2012, 58, 110-118. [CrossRef]

59. Błaszczyk, M.; Jania, J.A.; Hagen, J.O. Tidewater glaciers of Svalbard: Recent changes and estimates of calving fluxes. Pol. Polar Res. 2009, 30, 85-142.

60. Łoziński, W.V. Über die mechaniche Verwitterung der Sandsteine im gemässigten Klima. Acad. Sci. Crac. Bull. Int. Cl. Sci. Math. Nat. 1909, 1, 1-25.

61. Łoziński, W. Die periglaziale Fazies der mechanichen Verwitterung. Compte Rendus. In Proceedings of the XI Congrès Internationale Gèologie, Stockholm, Sweden, 17-25 August 1910; pp. 1039-1053.

62. French, H.M. The development of periglacial geomorphology: 1-up to 1965. Permafr. Periglac. Process. 2003, 14, 29-60. [CrossRef]

63. French, H.M. The Periglacial Environment, 2nd ed.; Longman: Harlow, UK, 1996.

64. Dabski, M.; Angiel, P. Geomorphic implications of the retreat of Breiðamerkurjökull in the southern part of the Skálabjörg ridge, Esjufjöll, Iceland. Jökull 2010, 60, 185-197.

65. Lovell, H.; Fleming, E.J.; Benn, D.I.; Hubbard, B.; Lukas, S.; Naegeli, K. Former dynamic behaviour of a cold-based valley glacier on Svalbard revealed by basal ice and structural glaciology investigations. J. Glaciol. 2015, 61, 309-328. [CrossRef]

66. Pettersson, R.; Jansson, P.; Holmlund, P. Cold surface layer thinning on Storglaciären, Sweden, observed by repeated ground penetrating radar surveys. J. Geophys. Res. Earth Surf. 2003, 108, 6004. [CrossRef]

67. Pettersson, R.; Jansson, P.; Huwald, H.; Blatter, H. Spatial pattern and stability of the cold surface layer of Storglaciären, Sweden. J. Glaciol. 2007, 53, 99-109. [CrossRef]

68. Dobiński, W.; Glazer, M. Probable two-layered permafrost formation, as a result of climatic evolution in mountainous environment of Storglaciären forefield, Tarfala, Northern Scandinavia. Pol. Polar Res. 2018, 39, 177-209. [CrossRef]

69. Etzelmüller, B.; Hagen, J.O. Glacier-permafrost interaction in Arctic and alpine mountain environments with examples from southern Norway and Svalbard. In Cryospheric Systems: Glaciers and Permafrost; Harris, C., Murton, J.B., Eds.; Special Publications; Geological Society: London, UK, 2005; Volume 242, pp. 11-27. [CrossRef] 
70. Kneisel, C. Permafrost in recently deglaciated glacier forefields-Measurements and observations in the eastern Swiss Alps and northern Sweden. Z. Geomorphol. 2003, 47, 289-305.

71. Kneisel, C. Permafrost in Gletschervorfeldern: Eine vergleichende Untersuchung in den Ostschweizer Alpen und Nordschweden; Trierer Geographische Studien 22; Universität Trier: Trier, Germany, 1999.

72. Kneisel, C. The nature and dynamics of frozen ground in alpine and subarctic periglacial environments. Holocene 2010, 20, 423-445. [CrossRef]

73. Baranowski, S. Naled type of ice in front of some Spitsbergen glaciers. In Results of investigations of the Polish Scientific Spitsbergen Expeditions 1970-1974; Baranowski, S., Jahn, A., Eds.; Acta Univ. Wratislav.: Wrocław, Poland, 1977; Volume 387, pp. 85-89.

74. Bukowska-Jania, E.; Szafraniec, J. Distribution and morphometric characteristics of icing fields in Svalbard. Polar Res. 2005, 24, 41-53. [CrossRef]

75. Kneisel, C.; Kääb, A. Mountain permafrost dynamics within a recently exposed glacier forefield inferred by a combined geomorphological, geophysical and photogrammetrical approach. Earth Surf. Process. Landf. 2007, 32, 1797-1810. [CrossRef]

76. Ruiz-Fernández, J.; Oliva, M. Relative Paleoenvironmental Adjustments Following Deglaciation of the Byers Peninsula (Livingston Island, Antarctica). Arct. Antarct. Alp. Res. 2016, 48, 345-359. [CrossRef]

77. Chang, M.; Jamieson, S.S.R.; Bentley, M.J.; Stokes, C.R. The surficial and subglacial geomorphology of western Dronning Maud Land, Antarctica. J. Maps 2016, 12, 892-903. [CrossRef]

(C) 2020 by the authors. Licensee MDPI, Basel, Switzerland. This article is an open access article distributed under the terms and conditions of the Creative Commons Attribution (CC BY) license (http://creativecommons.org/licenses/by/4.0/). 